\title{
Pathway from TDP-43-Related Pathology to Neuronal Dysfunction in Amyotrophic Lateral Sclerosis and Frontotemporal Lobar Degeneration
}

\author{
Yuichi Riku ${ }^{1,2, *(\mathbb{D})}$, Danielle Seilhean ${ }^{3,4,5}$, Charles Duyckaerts ${ }^{3,4,5}$, Susana Boluda ${ }^{3,5}$, Yohei Iguchi ${ }^{2}$,

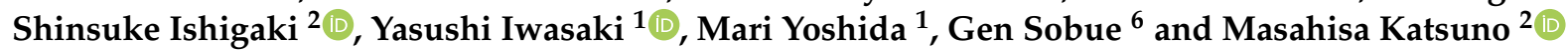 \\ 1 Institute for Medical Science of Aging, Aichi Medical University, Aichi 480-1195, Japan; \\ iwasaki@sc4.so-net.ne.jp (Y.I.); myoshida@aichi-med-u.ac.jp (M.Y.) \\ 2 Department of Neurology, Nagoya University, Nagoya 744-8550, Japan; iguyo@med.nagoya-u.ac.jp (Y.I.); \\ shinsuke.ishigaki@gmail.com (S.I.); ka2no@med.nagoya-u.ac.jp (M.K.) \\ 3 Department of Neuropathology Raymond Escourolle, Groupe Hospitalier Pitié-Salpêtrière Charles Foix, \\ AP-HP-Sorbonne Université, F-75013 Paris, France; danielle.seilhean@upmc.fr (D.S.); \\ charles.duyckaerts@aphp.fr (C.D.); susana.boludacasas@aphp.fr (S.B.) \\ 4 Faculty of Medicine, Sorbonne University, F-75013 Paris, France \\ 5 Paris Brain Institute (ICM), Inserm U 1127, CNRS UMR7225, Sorbonne University, F-75013 Paris, France \\ 6 Graduate School of Medicine, Aichi Medical University, Aichi 480-1195, Japan; sobueg@aichi-med-u.ac.jp \\ * Correspondence: likuliku23@yahoo.co.jp; Tel.: +81-561-62-3311
}

\section{check for} updates

Citation: Riku, Y.; Seilhean, D.; Duyckaerts, C.; Boluda, S.; Iguchi, Y.; Ishigaki, S.; Iwasaki, Y.; Yoshida, M.; Sobue, G.; Katsuno, M. Pathway from TDP-43-Related Pathology to

Neuronal Dysfunction in Amyotrophic Lateral Sclerosis and Frontotemporal Lobar Degeneration. Int. J. Mol. Sci. 2021, 22, 3843. https://doi.org/10.3390/ijms22083843

Academic Editor: Yazi Ke

Received: 19 March 2021

Accepted: 6 April 2021

Published: 8 April 2021

Publisher's Note: MDPI stays neutral with regard to jurisdictional claims in published maps and institutional affiliations.

Copyright: (c) 2021 by the authors. Licensee MDPI, Basel, Switzerland. This article is an open access article distributed under the terms and conditions of the Creative Commons Attribution (CC BY) license (https:// creativecommons.org/licenses/by/ $4.0 /)$.

\begin{abstract}
Transactivation response DNA binding protein $43 \mathrm{kDa}$ (TDP-43) is known to be a pathologic protein in amyotrophic lateral sclerosis (ALS) and frontotemporal lobar degeneration (FTLD). TDP-43 is normally a nuclear protein, but affected neurons of ALS or FTLD patients exhibit mislocalization of nuclear TDP-43 and cytoplasmic inclusions. Basic studies have suggested gain-of-neurotoxicity of aggregated TDP-43 or loss-of-function of intrinsic, nuclear TDP-43. It has also been hypothesized that the aggregated TDP-43 functions as a propagation seed of TDP-43 pathology. However, a mechanistic discrepancy between the TDP-43 pathology and neuronal dysfunctions remains. This article aims to review the observations of TDP-43 pathology in autopsied ALS and FTLD patients and address pathways of neuronal dysfunction related to the neuropathological findings, focusing on impaired clearance of TDP-43 and synaptic alterations in TDP-43-related ALS and FTLD. The former may be relevant to intraneuronal aggregation of TDP-43 and exocytosis of propagation seeds, whereas the latter may be related to neuronal dysfunction induced by TDP-43 pathology. Successful strategies of disease-modifying therapy might arise from further investigation of these subcellular alterations.
\end{abstract}

Keywords: ALS; autophagy; FTLD; synapse; TDP-43

\section{Introduction}

Transactivation response DNA binding protein $43 \mathrm{kDa}$ (TDP-43) is known to be a pathologic protein in amyotrophic lateral sclerosis (ALS) and frontotemporal lobar degeneration (FTLD) [1-3]. TDP-43 is an RNA-binding protein, which is coded on chromosome $1 \mathrm{p}$ [3]. Systemic organs, including the central nervous system, pancreas, and spleen, abundantly express TDP-43, but its physiological function is largely unknown [3]. TDP-43 is localized in the nucleus in normal settings, but affected neurons of ALS or FTLD patients exhibit mislocalization of nuclear TDP-43 and cytoplasmic inclusions. Pathological and molecular studies have suggested either gain-of-neurotoxicity of aggregated TDP-43 or loss-of-function of intrinsic, nuclear TDP-43. However, a mechanistic discrepancy between the TDP-43 pathology and neuronal dysfunctions remains. Recently, basic researches have reported that abnormalities in TDP-43 are associated with dynamic and complex alterations of neuronal substructures and metabolism. Concordant neuropathologic evidence has also been accumulated from postmortem patient studies of TDP-43-related ALS or 
FTLD (ALS-TDP and FTLD-TDP, respectively). This review aims to discuss pathways from TDP-43 pathology to mechanisms leading to neuronal dysfunction.

\section{Clinical Findings of ALS and FTLD}

ALS encompasses a sporadic or familial motor neuron disease, which is clinically characterized with upper and lower motor neuron signs and symptoms [4]. The muscle weakness is relentlessly progressive and lethal. The median survival duration is about three years from disease onset, and the average age of onset is 58-60 years [5]. The prevalence is approximately six cases per 100,000 [5]. Several clustered regions are known to have a high prevalence of ALS, including Guam island of USA, Kii peninsula of Japan, and West New Guinea. Patients in the clustered foci often show a phenotype of parkinsonism-dementia complex (ALS/PDC) that is atypical of classical ALS. The prevalence has recently decreased in these regions for unknown reasons, although it is still high in New Guinea [6].

FTLD is the pathological term corresponding to the clinical term of frontotemporal dementia (FTD) [7]. FTD is the second most common form of dementia after Alzheimertype dementia. A study from the UK reported that the prevalence of FTLD was 10.8 per 100,000 population and highest between 60 and 69 years, although the data set also included progressive supranuclear palsy (PSP) and corticobasal syndrome [8]. FTD is subclassified into behavioral variant FTD (bvFTD) [9], progressive non-fluent aphasia (PNFA) [10], and semantic dementia (SD) [10]. bvFTD is characterized by disinhibition and executive disorders and more common than PNFA and SD. PNFA and SD manifest as impairment of output and input of language, respectively.

\section{TDP-43 Pathology in ALS and FTLD}

There is a loss of upper and lower motor neurons in ALS patients, which results in regional atrophy. Atrophy of the anterior roots is the most informative finding upon macroscopic observations, whereas that of the primary motor cortex is usually mild (Figure 1). TDP-43 pathology has been observed in 95\% of sporadic ALS cases [11,12], followed far behind by fused-in-sarcoma (FUS) $[13,14]$. TDP-43 is mislocalized from the nucleus and aggregates in the cytoplasm of motor neurons in ALS patients (Figure 2). Aggregated TDP-43 is phosphorylated, ubiquitylated, and truncated at the C-terminal side $[15,16]$. The TDP-43 pathology is more prominent in the lower motor neurons in the spinal cord and cranial nerve nuclei than in the upper motor neurons (Betz cells) of the primary motor cortex. Although eye movement, sensation, and urorectal functions are spared in ALS patients, TDP-43 pathology has occasionally been found in the oculomotor nerve nucleus, Clarke column, and Onuf nucleus [17,18]. Another finding of importance in ALS is Bunina bodies, which are eosinophilic inclusion bodies found in the neuronal cell body. Bunina bodies are an accumulation of tubular and vesicular structures from unknown origin and do not represent a cytoplasmic aggregation of TDP-43, although a subset of those demonstrates immunoreactivity to TDP-43 [19,20].

In FTLD, TDP-43 and tau each accounts for nearly 50\% [21]. FTLD-TDP is currently subclassified into pathological types A, B, and C [22-24]. Type A is characterized by TDP43-immunoreactive, short dystrophic neurites, and cytoplasmic inclusions in the upper cortical layers. In type B, crescent or ring-shaped cytoplasmic aggregation of TDP-43 are observed across all cortical layers. Type $\mathrm{C}$ is characterized by TDP-43 immunopositive thick and long dystrophic neurites in the upper cortical layers, and cytoplasmic inclusions are rare. The frontotemporal neocortices are vulnerable, and the hippocampus, the amygdala, the neostriatum, and the substantia nigra are also preferentially involved with TDP-43 pathology [25,26] (Figure 2). Cortical TDP-43 pathology often spreads toward more posterior areas than prefrontal areas, in contrast to the topography of Pick disease lesions. The distribution of FTLD lesions largely corresponds to clinical phenotypes of FTD: involvement of frontal and temporal cortices is seen in bvFTD; that of the anterior temporal cortices is seen in SD, and that of the frontal cortices and para-Sylvian areas is seen in PNFA [27] (Figure 1). 
ALS-TDP and FTLD-TDP may overlap clinically or pathologically [28]. ALS-TDP and FTLD-TDP often coexist in the same individuals; this phenotype is currently termed frontotemporal dementia with motor neuron disease (FTD-MND). Regions vulnerable to the TDP-43 pathology are often the same in ALS-TDP and FTLDTDP. For example, TDP43 aggregations in the hippocampus were found in $40 \%$ of the non-demented ALS-TDP patients, whereas TDP-43 aggregations in the spinal cord motor neurons were found in $90 \%$ of the FTLD-TDP patients even in the absence of motor neuron signs or symptoms [29,30]. It has been suggested that ALS-TDP and FTLD-TDP could be a part of a continuous spectrum of diseases, 'TDP-43 proteinopathy' [28]. However, molecular assays of aggregated TDP43 have revealed different molecular properties between ALS-TDP and FTLD-TDP and among pathological subtypes of FTLD-TDP. The molecular weights of $C$-terminal fragments of aggregated TDP-43 differ among FTLD-TDP type A, B, and C, and ALS [15,31]. In addition, a recent study revealed that molecular size, density, structure, and neurotoxicity differ among the subtypes of TDP-43 proteinopathy [32]. This evidence indicates the possibility of a distinctive, at least partially, molecular pathway of TDP-43 aggregation in each pathological phenotype of TDP-43 proteinopathy.

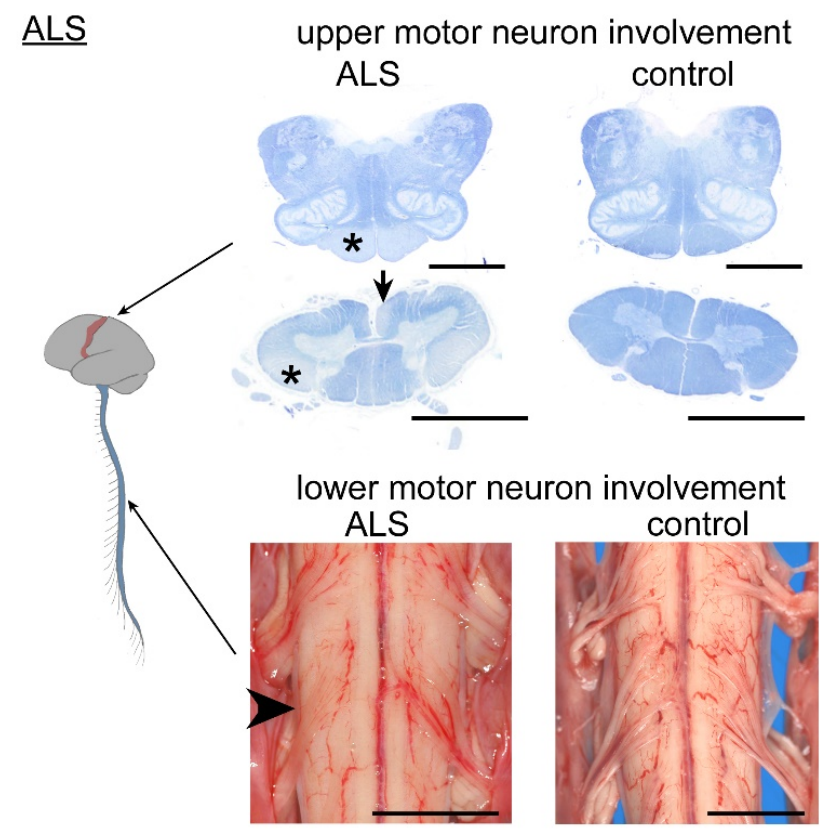

$\underline{\text { FTLD }}$

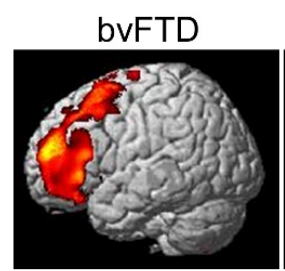

PNFA

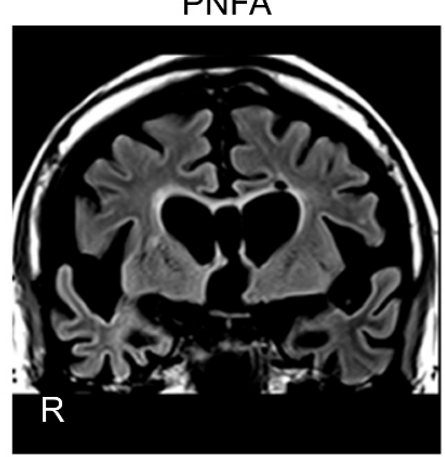

PNFA
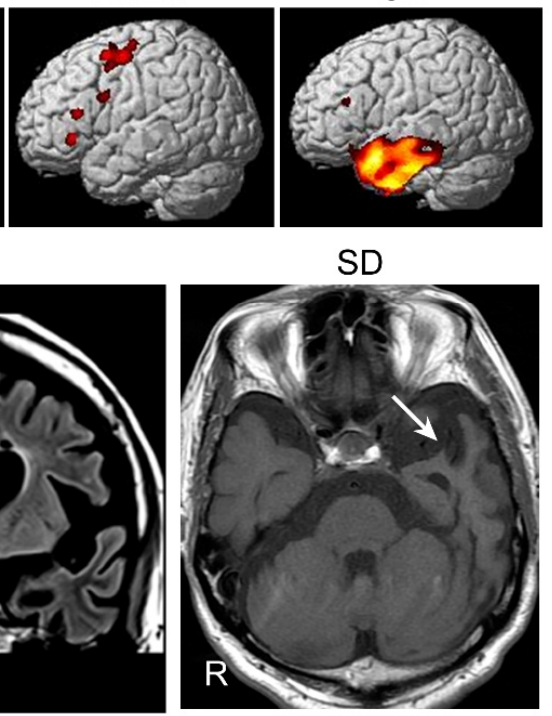

Figure 1. Systemic atrophy of central nervous system in amyotrophic lateral sclerosis (ALS) and frontotemporal lobar degeneration (FTLD) patients. The spinal cord and medulla oblongata are stained with Klüver-Barrera method. Involvement of the upper motor neurons results in tract degeneration of the pyramidal tract in the medullary pyramid and lateral column $\left({ }^{*}\right)$ and anterior cerebrospinal fasciculus (arrow) of the spinal cord; the change is usually prominent in the caudal segments of the spinal cord. Involvement of the lower motor neurons results in atrophy of the anterior roots in the spinal cord (arrowhead); the anterior roots are thin and hardly visible, compared with the dorsal roots. Scale bars $=5 \mathrm{~mm}$. Cerebral MRI illustrates a vulnerable region corresponding to each clinical subtype: the prefrontal area for behavioral variant frontotemporal dementia (bvFTD), the para-Sylvian operculum and primary motor cortex for progressive non-fluent aphasia (PNFA), and the anterior portion of the unilateral (dominant hemisphere) temporal lobe for SD (arrow). 


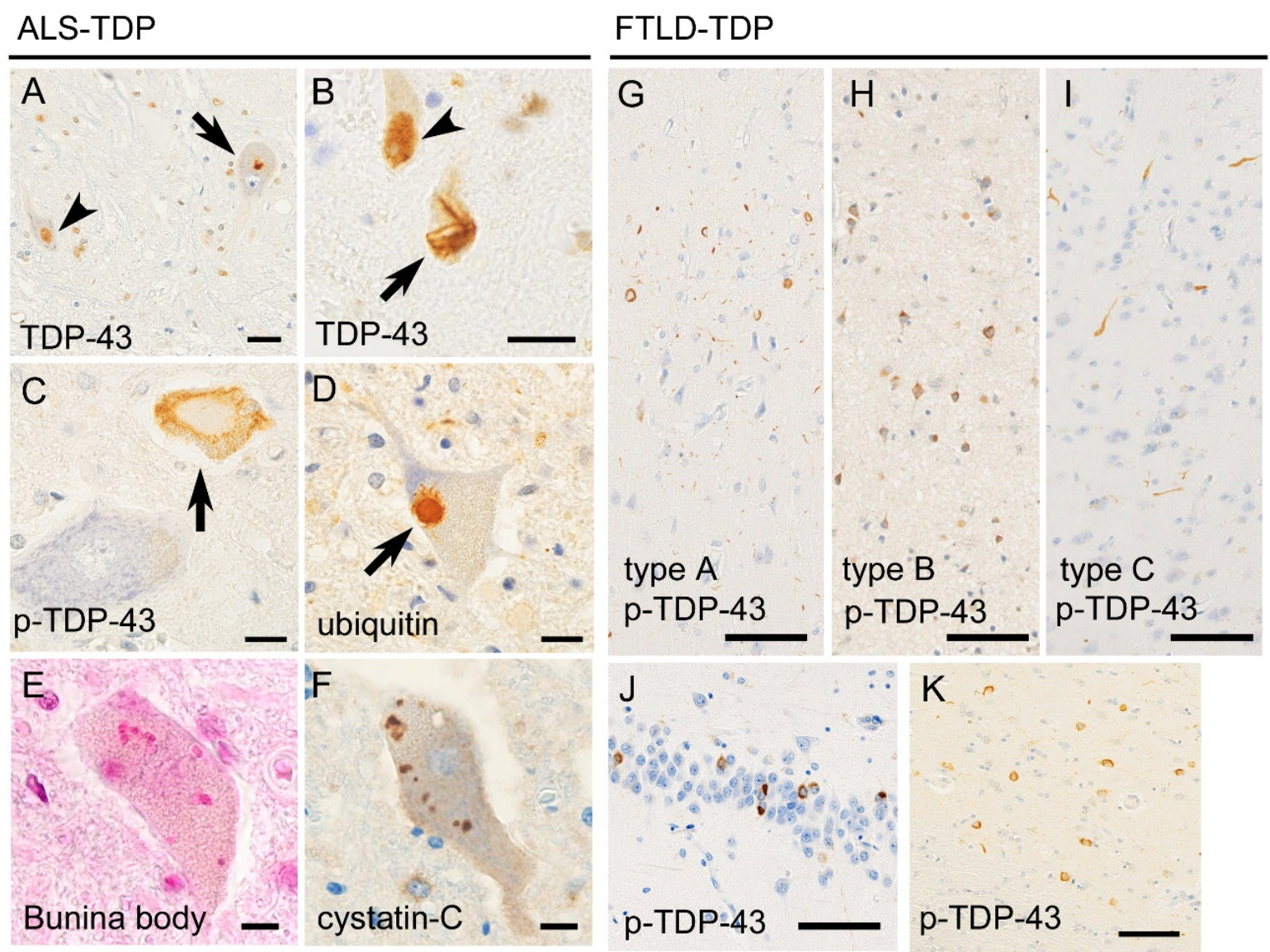

\section{ALS/PDC (Kii peninsula, Japan)}

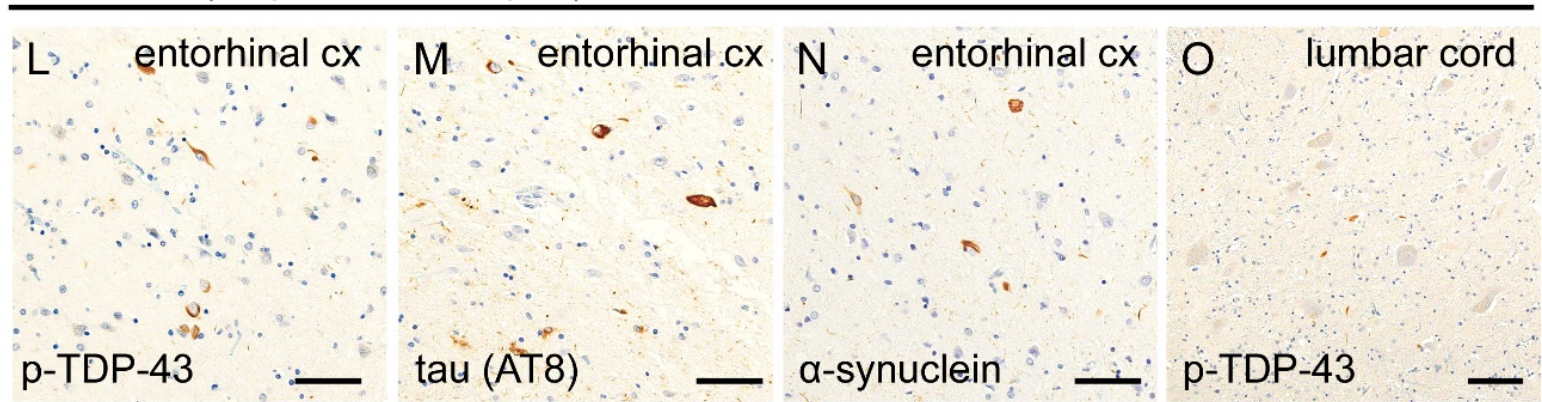

Figure 2. Histopathological findings of transactivation response DNA binding protein 43kDa (TDP-43)-related ALS (ALSTDP) and FTLD (FTLD-TDP). Panels A-D were taken from an ALS-TDP patient. Anti-TDP-43 immunohistochemistry revealed that TDP-43 was mislocalized from the nucleus to the cytoplasm and forms dot-like (A, arrow) or skein-like inclusions (B, arrow) in the spinal motor neuron. Unaffected neurons showed nuclear localization of TDP-43 (A and B, arrowheads). Anti-phosphorylated TDP-43 (p-TDP-43) immunohistochemistry revealed pathologic inclusions (C, arrow) but not the normal nuclear expression of TDP-43. TDP-43 inclusions were immunopositive for ubiquitin (D, arrow). Bunina bodies are also observed in the motor neurons of ALS-TDP patients (E) and immunolabeled with cystation-C (F). Panels G-K were taken from FTLD-TDP patients. Sporadic FTLD-TDP is classified into types A, B, and C; type A is characterized by short dystrophic neurites and round- or crescent-shaped neuronal inclusions in the superficial layers of the cerebral cortex; type B is characterized by ring-shaped neuronal inclusions across all cortical layers; and type C is characterized by long and thick immunopositivity of neurites in the superficial cortical layers (G-I). Hippocampal granule cells (J) and neostriatum $(\mathbf{K})$ are also preferentially involved. Panels (L-O) were taken from an ALS/ parkinsonism-dementia complex (PDC) (Kii peninsula) patient. The entorhinal cortex (L-N) showed multiple proteinopathies, including p-TDP-43 (L), hyperphosphorylated tau (M), and $\alpha$-synuclein (O). Relatively mild aggregation of p-TDP-43 was observed in the spinal cord, compared with classical ALS. Scale bars: (A,B) $20 \mu \mathrm{m},(\mathbf{C}-\mathbf{F}) 10 \mu \mathrm{m}$, and (G-O) $50 \mu \mathrm{m}$. 


\section{Gain-of-Neurotoxicity and Loss-of-Function}

These ambivalent concepts may have arisen from the double face of TDP-43 pathology: cytoplasmic aggregation and mislocalization from the nucleus. It is broadly believed that the cytoplasmic inclusions of TDP-43 are neurotoxic. Neuronal death or axonal dysfunction has been observed in models with overexpression of TDP-43 [33] and cells transfected with pathological TDP-43 mutants [34,35] or cytoplasmically mislocalized TDP-43 with mutated nuclear localization signals (NLSs) [36]. How aggregated TDP-43 triggers neuronal death or dysfunction remains controversial. By contrast, evidence of loss-of-function of TDP-43 mechanisms has also been accumulated. Transgenic mice expressing human TDP-43 with a mutated NLS displayed neuronal loss and tract degeneration. Endogenous nuclear TDP-43 is downregulated, and cytoplasmic inclusions were sparse. These facts suggest that the loss of nuclear TDP-43 is more strongly correlated with neuronal dysfunction than is the cytoplasmic inclusions [37]. Other TDP-43 suppression or knock-out models also showed neuronal dysfunction, including an alteration of TDP-43-related transcriptome resulting in synaptic abnormality [38], deficits in DNA repair [39], a loss of splicing repressor function [40], and dsRNA-foci [41].

\section{Anatomical Spreading of TDP-43 Pathology}

Neuropathologic analyses of autopsied patients with ALS-TDP and FTLD-TDP have indicated that TDP-43 pathology spreads along certain neurally connected anatomical systems rather than depending on spatial proximity. Direct or indirect corticofugal spreading of TDP-43 pathology from the primary motor cortex to the lower motor neurons has been suggested in ALS-TDP patients [42,43]. In FTLD-TDP, cortico-cortical spreading from prefrontal areas to caudal cortices has been proposed [44]. Subcellular observations revealed granular aggregates of phosphorylated TDP-43 (p-TDP-43) within the axons and axonal terminals of ALS-TDP and FTLD-TDP patients, which indicates an intra-axonal transfer of the aggregates $[43,45,46]$. This finding is often observed in patients with short clinical duration (Figure 3) [47]; hence, p-TDP-43 aggregations might be transferred through the axons even in the early stages of the disease.

Premortem neurophysiological studies have supported a corticofugal manner in the spreading of ALS lesions. Studies of transcranial magnetic stimulation revealed that reduction in short-interval intracortical inhibition precedes lower motor neuron dysfunction among ALS patients, indicating early impairment of intracranial circuit within the primary motor cortex [48]. Structural [49-51] and functional [52] imaging technics have also suggested the corticofugal manner of ALS lesions; for instance, a study of resting-state functional MRI showed that patterns of increased connectivity, relevant to network expansion and physical disability, were consistent with spreading patterns of TDP-43 pathology in ALS [52].

Other patterns in the spreading of TDP-43 pathology have also been suggested. A neuropathological study suggested that the dentate gyrus of the hippocampus is a starting point for TDP-43 pathology in ALS-TDP and FTD-MND; the pathology may subsequently spread to the anterior olfactory nucleus, the periamygdaloid complex, the piriform cortex and eventually reach the orbital cortex and olfactory bulb [53,54]. Moreover, TDP-43 aggregates and dipeptide repeat proteins systematically involve the circadian sleep/wakeassociated regions, including the pineal body and hypothalamic neurons related to the suprachiasmatic nucleus, in ALS patients with C9orf72 repeat expansion [55].

Molecular biological studies have revealed propagative properties of TDP-43 aggregates. Full-length TDP-43 contains NLSs, whereas the C-terminal fragments do not [16]. Therefore, the fragments are considered to be more often present in the cytoplasm than full-length sequences and are thus good candidates as 'seeds' for aggregations [16,36,37]. Induction of patient-derived TDP-43 seeds resulted in the spreading of TDP-43 aggregates in a cell-to-cell and in a corticofugal manner for SH-SY5Y cells and mice with a mutated human TDP-43 NLS (CamKIIa-hTDP-43NLSm), respectively [16,56]. 
A
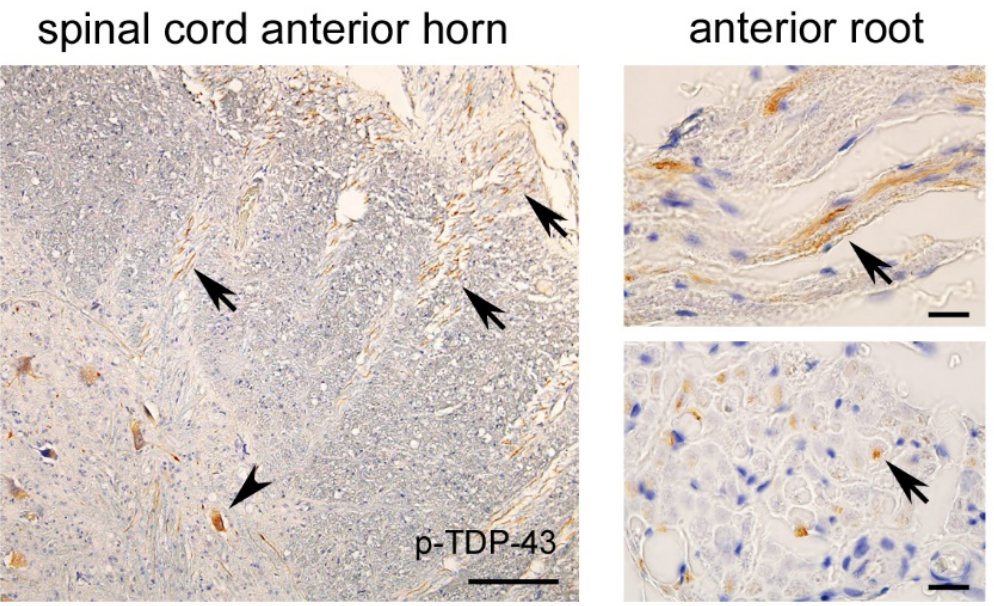

B

\section{terminal of cortico-striatal projection}

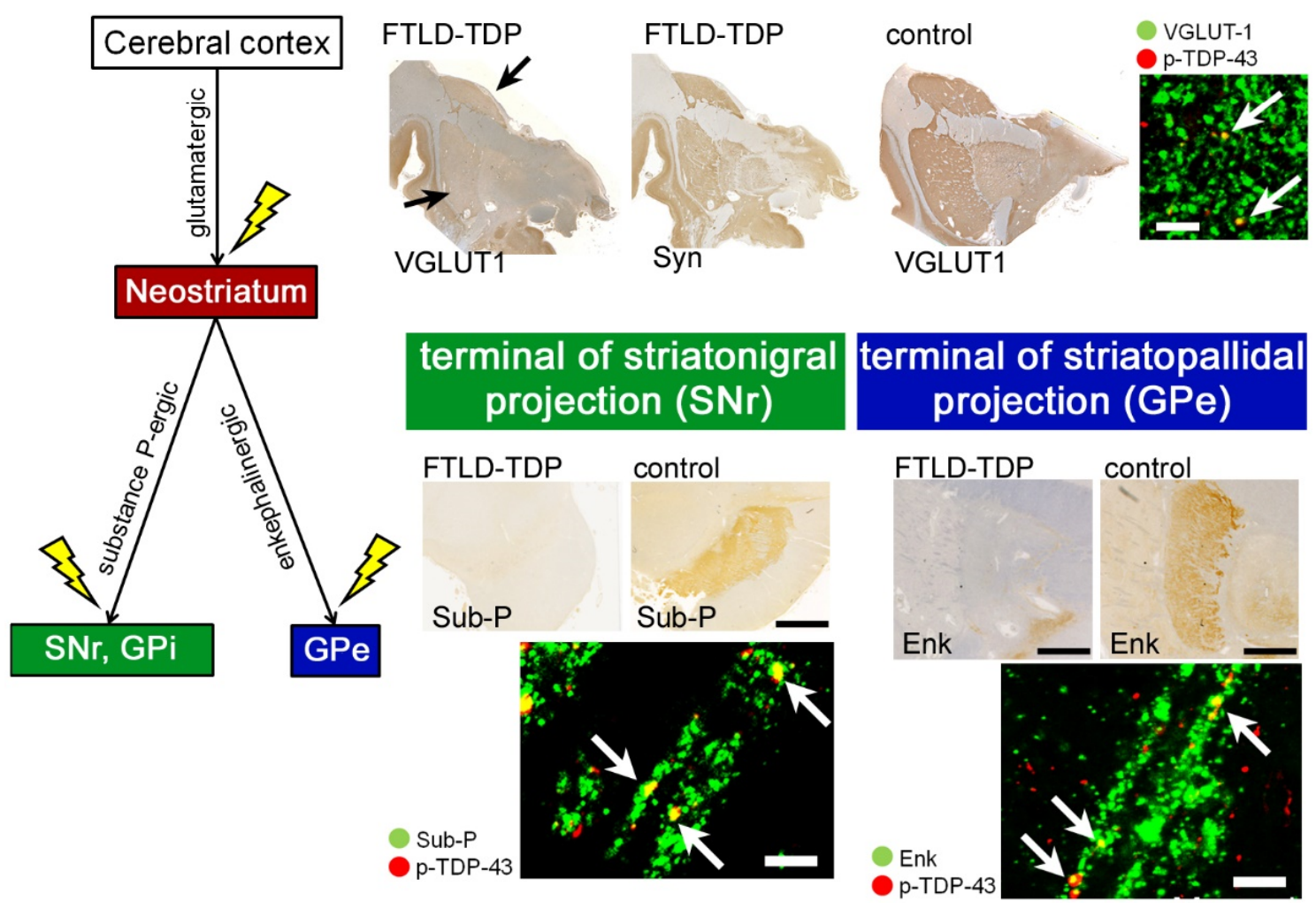

Figure 3. TDP-43 pathology in multi-system axons and axon terminals. The upper section (A) demonstrates the spinal cord of an ALS-TDP patient who died six months after the disease onset. Phosphorylated TDP-43 (p-TDP-43) aggregated not only in the anterior horn neurons (arrowhead) but also in the anterior roots (arrows). Scale bars: $100 \mu \mathrm{m}$ for the panel of the anterior horn and $10 \mu \mathrm{m}$ for the panels of the anterior roots. The lower section (B) displays pathologic changes of the cortico-striatal circuit in FTLD-TDP patients. Axon terminals of the corticofugal neurons were visualized with anti-VGLUT-1 immunohistochemistry (IHC) in the neostriatum. Those of the striatofugal neurons were labeled with anti-enkephalin (Enk) IHC in the external segments of the globus pallidus (GPe) or with anti-substance-P (Sub-P) IHC in the internal segment of GP (GPi) and pars reticulata of the substantia nigra (SNr). Patients with FTLD-TDP displayed loss of those axon terminals and p-TDP-43 aggregation within the pre-synaptic buttons. Comparing the loss of VGLUT-1-immunopositive terminals in the neostriatum (arrows) and sparing of synaptophysin (Syn) immunostaining indicates specific loss of cortico-striatal projections but spares of other projections. Scale bars: $10 \mu \mathrm{m}$. 


\section{Are ALS-TDP and FTLD-TDP Synaptopathies?}

Ultrastructural observations of autopsied ALS patients revealed degradation of axon terminals in the motor neuron system, associated with alterations of pre-synaptic vesicles, mitochondria, and neurofilament bundles [57,58]. We have found loss of axon terminals in cortico-striatal projections, striatopallidal projections, and striatonigral projections in autopsied ALS-TDP and FTLD-TDP patients using immunolabeling of glutamatergic or GABAergic pre-synaptic vesicles [45,46] (Figure 3). The depletion of axon terminals was more severe in FTLD-TDP patients than in ALS-TDP patients without dementia. Aggregation of p-TDP-43 was also found within the remaining terminals. A recent study quantified axonal terminal densities with high precision using array tomography. It revealed significant depletion of axonal endings in the prefrontal cortex and its correlation with cognitive decline in ALS patients [59].

Studies using models of increased expression of TDP-43 have reported a loss of axon terminal or dendritic spines. It has also been suggested that TDP-43 is physiologically transported within the axons and contributes to axonal outgrowth [60]. Mice overexpressing human-TDP-43 showed reductions in the expression of mRNAs that encode proteins involved in pre-synaptic activity via an RNA-binding property of TDP-43 [61]. It is unknown whether the aggregation of p-TDP-43 within axonal terminals demonstrates in situ synaptotoxicity, which has been reported for a tauopathy model; induction of pathogenic mutant tau bound to pre-synaptic vesicles and disrupted synaptic functions [62]. Depletion of TDP-43 in neurons or microglia has also been reported to be correlated with synaptic loss, impairment of synaptic plasticity, alterations in RNA transcripts that are closely relevant to synaptic plasticity, or disruption of axonal growth [38,63-65]. We also found that FUS, which is the second most common pathological protein in ALS, plays a role in synaptic functions. Downregulation of FUS expression by shRNA resulted in depletion of dendritic spines and AMPA receptors and a loss of spine plasticity in primary cortical neurons and mice, respectively [66]. Synaptopathy might explain the neuronal dysfunction in a broad spectrum of disorders related to ALS and FTLD.

\section{Impaired Clearance of TDP-43}

Aggregated TDP-43 is ubiquitylated and tagged with p62, which indicates a contribution of ubiquitin-proteasome and endosome-autophagy systems to process the aggregates. The role of p62 would be to guide the ubiquitylated proteins towards the autophagy system [67]. A neuropathological study reported that a subset of TDP-43 aggregates is immunopositive for LC3 [68], which is an autophagosomal marker [60]. Activation of the autophagosome-lysosome system has been reported to decrease the neurotoxicity of aggregated TDP-43 in neuron models $[69,70]$. In a yeast model, increased TDP-43 level disrupted the fusion and function of vesicles linked to the autophagy-lysosome system [71]. In addition, we have shown the importance of exosomes, which are another endosomemediated clearance mechanism in the metabolism of TDP-43 (Figure 4). Neuro2a cells that were transfected with human-strain TDP-43 secreted the exogeneous TDP-43 with the exosomes [72]. Moreover, high levels TDP-43 and insoluble C-terminal fragments were found in the exosome fraction, which was extracted from FTD-MND patients' brains. Inhibition of exosomes resulted in intracytoplasmic mislocalization and aggregation of TDP-43. Intake of exosome carrying C-terminal fragments into the cells also facilitated the TDP-43 pathology. These facts indicate that exosomal secretion of TDP-43 is a critical step in TDP-43 metabolism and that secreted TDP-43 functions as a seed for neuron-to-neuron propagation of TDP-43 [16,73]. When considering together with a concept of synaptopathy, it can be hypothesized that transmission of TDP-43 seeds between pre- and post-synapse, depending on the exocytosis, could be a mechanism of centrifugal, anatomical propagation of TDP-43 pathology. Exosomal fraction is also identified in plasma and cerebrospinal fluid (CSF). However, whether exosomal TDP-43 levels are elevated there in patients with ALS is controversial [74]. 
A

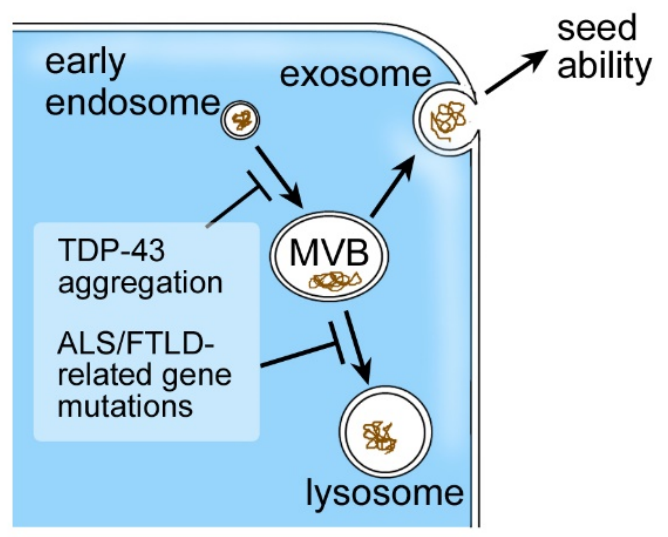

exosomal TDP-43 of ALS patients

B

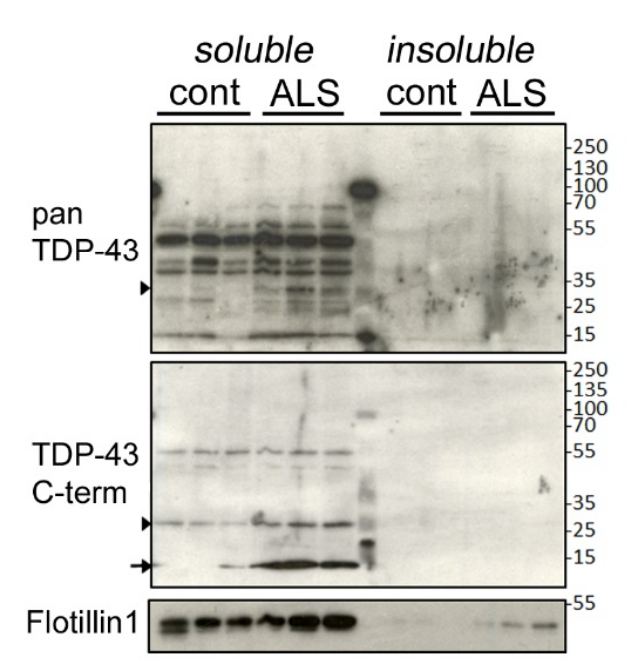

C
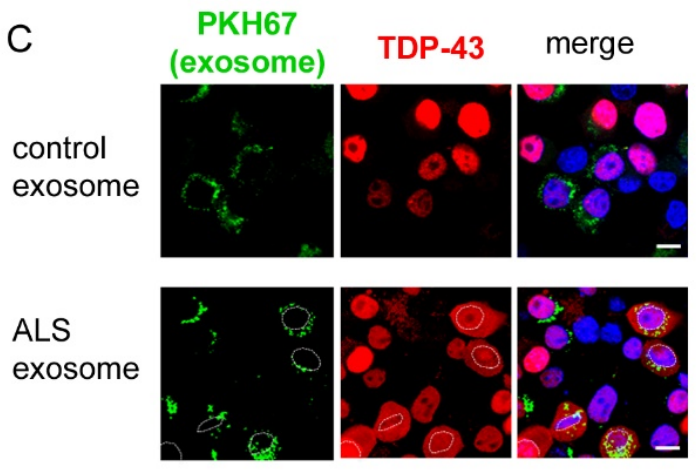

Figure 4. Endosome-autophagosome system and TDP-43 pathology. (A) Aggregated TDP-43 and dysfunction/haploinsufficiency of ALS/FTLD-TDP-related genes have been reported to impair maturation, transport, or fusion of endosomal and autophagosomal vesicles. (B) The exosomal fraction of brain lysates from ALS-TDP patients contains abundant TDP-43, particularly C-terminal fragments. (C) Neuro2a cells that were treated with ALS-patients-derived exosome and transfected with human-derived TDP-43 exhibited cytoplasmic aggregation of TDP-43. (D-F) These panels show neuropathologic changes of ALS/FTLD-TDP patients carrying C9-orf72 hexanucleotide expansions. Hippocampal pyramidal neurons often displayed granulovacuolar degeneration (GVD) that was associated with immunoreactivity for CHMP2B, a marker of multivesicular bodies (MVBs) (D). GVD granules, which were immunolabeled with CHMP2B and CK1ס, contained p-TDP-43 and hyperphosphorylated tau (E). Mutation-derived sense (poly GA, poly GP, and poly GR) and antisense dipeptides (poly PR and poly PA) were frequently covered with CHMP2B-immunopositive GVD granules. Scale bars: $10 \mu \mathrm{m}$. 
ALS-TDP- or FTLD-TDP-related genes, including SQSTM1 (p62), UBQLN2, VCP, GRN, and OPTN, are important players in the autophagy system [75]. Indeed, homozygous mutations of the GRN gene cause neuronal ceroid lipofuscinosis, which is characterized by lysosomal storage of lipopigment [76]. Haploinsufficiency of C9orf72 correlated to disruption of autophagy, particularly of endosomal trafficking [77]. Upon our postmortem observations, the hippocampi and frontal cortices of C9orf72-mutated patients frequently and broadly displayed granulovacuolar degeneration (GVD) containing an accumulation of CHMP2B (charged multivesicular body protein 2B) [78]. CHAMP2B is a marker of the multivesicular body, which is the turning point of the lysosome or exosome pathway. CHMP2B-immunopositive vesicles of GVD often coexisted with dipeptide repeat proteins, derived from non-ATG-dependent translation of repeat sequences [78,79]. A mutation in the $C H M P 2 B$ gene is also known to cause familial FTD, although the postmortem findings remain unknown [80]. A recent study reported that GVDs carrying necrosome-markers were primarily found in the hippocampus of ALS-TDP and FTLD-TDP with and without C9orf72 mutation [81].

It is well known that chaperone proteins are critical to regulating the folding or solubility of pathologic proteins in motor neuron diseases and other neurodegenerative disorders [82,83]. A comprehensive study has revealed that the heat-shock response reduced insoluble, phosphorylated TDP-43 and was suppressed in spinal cord tissues of sporadic ALS-TDP patients [84]. It has also been reported that chaperon-mediated autophagy (CMA), which specifically directs the degradation of soluble proteins, regulates TDP-43 metabolism under physiological and pathologic conditions and that aggregated TDP-43 affects the integrity of CMA-associated lysosomes [85]. Degradation of liquidliquid phase separation along with aging, genetic, or environmental factors, followed by reduction in HSP-70, has been reported to perturb the solubility of TDP-43 [86]. A postmortem study hypothesized that abnormal but soluble TDP-43 in the Betz cells, where TDP-43 pathology is considered to be initiated, could be an early mechanism of ALS; the hypothesis arose from the fact that aggregation of p-TDP-43 was relatively sparse in the Betz cells compared with mislocalization of nuclear TDP-43 [87]. Full-length TDP-43, the $45 \mathrm{kDa}$ form, and ubiquitylated TDP-43 have been found in the soluble, inclusion-free fraction of brain tissues from ALS-TDP patients, which indicates that mislocalization of TDP-43, preceding the aggregation, play a role in the early pathogenesis of ALS [88].

In addition to the intraneuronal machinery, neuroinflammation toward TDP-43 aggregation has been emphasized. A study revealed high extracellular expression of a neuroinflammatory marker, cyclophilin-A, in CSF from SOD-1 ${ }^{\mathrm{G} 93 \mathrm{~A}}$ models and sporadic ALS patients, and drug-derived inhibition of cyclophilin-A reduced nuclear factor kappa $\mathrm{B}(\mathrm{NF}-\mathrm{KB})$ activation, endoplasmic reticulum stress, and insoluble phosphorylated TDP43 [89]. From the viewpoint of neuroinflammation, the pathophysiological importance of glial reactions increases. Recent studies revealed neuroprotective properties of astrocytes and microglia, of which activation and proliferation reduce pathological TDP-43 levels $[90,91]$. Impacts of altered glial expression of TDP-43 have also been investigated. A study of primary-cultured astrocytes suggested that knock-down of TDP-43 facilitated neuroinflammatory along with elevated NF-KB and dsRNA-foci [92], whereas a contradictory study described no influences of it toward astrocytic activation and neuronal survival [93].

\section{Linkage between TDP-43 and tau Pathology}

Postmortem studies have demonstrated that TDP-43 pathology is observed in a subset of non-ALS/FTLD disorders, including Alzheimer disease (AD) [94,95], PSP [96], corticobasal degeneration (CBD) [97], Lewy body disease (LBD) [98-101], hippocampal sclerosis [102], LRRK-2 mutated Parkinson disease [103], and post-traumatic chronic encephalopathy [104]. Subpopulations (up to $20 \%$ ) of neurologically healthy, aged people also show TDP-43 aggregation in the limbic systems, which is referred to as limbic-predominant age-related TDP-43 encephalopathy (LATE) [105].

The prevalence of TDP-43 pathology is particularly high in AD patients and accounts for up to $75 \%$ [94,95]. Impacts on clinical manifestations or on brain atrophy of the co- 
morbid TDP-43 pathology in AD, PSP, and CBD patients have been reported [94,96,97], although whether the comorbid TDP-43 pathology is 'bystander' or 'pathogenic' is still controversial [106]. The molecular basis of comorbid TDP-43 pathology in miscellaneous disorders remains unclear. At least, the spatial distribution, the spreading pattern, and the morphology of TDP-43 aggregations partially but definitely differ from those observed in patients with ALS-TDP or FTLD-TDP. This is in great contrast with the reported similarities between AD-related tau pathology and primary age-related tauopathy [107].

Additionally, abnormalities in tau protein have also been discussed in ALS-TDP patients. Aggregation or hyperphosphorylation of tau has been observed in the motor neurons of ALS-TDP patients [108,109]. It has been reported that FTLD-TDP patients carrying C9orf72-repeat expansions tended to have a higher burden of tau aggregations in the temporal cortex and hippocampus than GRN-mutated patients [110]. However, contradictory results have also been reported; a cohort-based study of autopsied FTLD/ALS-TDP and FTLD-tau indicated no predisposition towards TDP-43 pathology in FTLD-tau patients or to tau pathology in FTLD-TDP patients [111]. ALS/PDC patients of Kii peninsula, Japan, often exhibit multiple proteinopathies, including TDP-43, tau, and $\alpha$-synuclein, prominently in the limbic system (Figure 2); interestingly, the aggregation is usually mild in the motor neurons [112]. Although the genetic background and pathogenesis of this phenotype are still unknown, recent neuropathological studies have revealed that mutant ubiquitin $\left(\mathrm{UBB}^{+1}\right)$ is highly expressed in the hippocampus or cerebral cortices, and dyshomeostasis of the ubiquitin-proteasome system is suggested [113].

The coexistence of TDP-43 and tau pathologies suggests overlapped mechanisms between these two major groups among neurodegenerative disorders. Our observations revealed that the hippocampal and cortical neurons of autopsied patients with ALS/FTLD-TDP, ALS-FUS, PSP, and CBD showed aberrant interaction of two intranuclear proteins, namely, FUS and splicing factor proline/glutamine-rich proteins (SFPQ) [114,115]. FUS and SFPQ are physiologically co-localized within the neuronal nuclear matrix, whereas they are spatially and biochemically dissociated in disease. Importantly, the dissociation of FUS and SFPQ was not observed in AD or Pick disease patients and neurologically healthy controls. An investigation using human mutant-TDP-43-knock-in mice showed alterations in splicing of microtubule-associated protein tau (MAPT) gene [116]. Genome analyses revealed shared genetic risks across PSP, CBD, FTD, and FTD-MND [117,118]. Intermediate repeat expansion in C9orf72 has recently been reported to be a risk factor for CBD [119]. Upon postmortem observations of AD or CBD brains, intracellular TDP-43 aggregates and tau aggregates sometimes seem to be co-localized and sometimes not $[101,120]$. It remains to be clarified whether the coexistence of TDP-43 and tau pathology signifies a common mechanism upstream of pathogenesis or a process secondary to aggregation of either protein.

\section{Conclusions}

Recent studies have revealed correlations between TDP-43 abnormalities and impairment of some cellular substructures. We focused on the involvement of the endosomeautophagosome system and synaptic integrity as key actors in the pathogeneses of TDP-43 proteinopathy from the viewpoint of translational approaches across neuropathological and basic investigations. The concept of multiple proteinopathies, including interactions between TDP-43 and tau, suggests a pathophysiological link at a very early stage before protein aggregation. Although the whole pathway leading to neuronal dysfunction remains unclear, successful strategies of disease-modifying therapy may arise from those results.

Author Contributions: Conceptualization, Y.R. and Y.I. (Yohei Iguchi); methodology, Y.R., S.I. and Y.I. (Yohei Iguchi); software, Y.R.; validation, C.D., D.S. and S.B.; formal analysis, G.S.; investigation, Y.R. and Y.I. (Yohei Iguchi); resources, Y.R.; data curation, M.K.; writing-original draft preparation, Y.R.; writing-review and editing, S.B., D.S., C.D. and Y.I. (Yasushi Iwasaki); visualization, G.S.; supervision, M.K., M.Y. and Y.I. (Yasushi Iwasaki); project administration, Y.R.; funding acquisition, Y.R. All authors have read and agreed to the published version of the manuscript. 
Funding: This research received no external funding.

Institutional Review Board Statement: Not applicable.

Informed Consent Statement: Not applicable.

Data Availability Statement: No new data were created or analyzed in this study. Data sharing is not applicable to this article.

Acknowledgments: We appreciate the collaboration of all laboratory staff in the Institute for Medical Science of Aging, Aichi Medical University, Japan and in the Department of Neuropathology Raymond Escourolle, Groupe Hospitalier Pitié-Salpêtrière, France. We thank the NeuroCEB network and platform for providing samples and technical advice. The work was partially supported by JSPS KAKENHI Grant Number JP20K16586 (Y.R.).

Conflicts of Interest: The authors declare no conflict of interest. The funders had no role in the design of the study.

\section{Abbreviations}

\begin{tabular}{|c|c|}
\hline $\mathrm{AD}$ & Alzheimer disease \\
\hline ALS & amyotrophic lateral sclerosis \\
\hline ALS-TDP & TDP-43-related ALS \\
\hline bvFTD & behavioral variant FTD \\
\hline CBD & corticobasal degeneration \\
\hline СHMP2B & charged multivesicular body protein $2 \mathrm{~B}$ \\
\hline CK1 $1 \delta$ & casein kinase $1 \delta$ \\
\hline CMA & chaperon-mediated autophagy \\
\hline CSF & cerebrospinal fluid \\
\hline FTD & frontotemporal dementia \\
\hline FTD-MND & frontotemporal dementia with motor neuron disease \\
\hline FTLD & frontotemporal lobar degeneration \\
\hline FTLD-TDP & TDP-43-related FTLD \\
\hline FUS & fused-in-sarcoma \\
\hline GVD & granulovacuolar degeneration \\
\hline HSP-70 & $70 \mathrm{kDa}$ heat shock proteins \\
\hline LATE & limbic-predominant age-related TDP-43 encephalopathy \\
\hline LBD & Lewy body disease \\
\hline MAPT & microtubule-associated protein tau \\
\hline MVB & multivesicular body \\
\hline$N F-\kappa B$ & nuclear factor kappa B \\
\hline PDC & parkinsonism-dementia complex \\
\hline PNFA & progressive non-fluent aphasia \\
\hline PSP & progressive supranuclear palsy \\
\hline SD & semantic dementia \\
\hline SFPQ & splicing factor proline/glutamine-rich proteins \\
\hline TDP-43 & Transactivation response DNA binding protein $43 \mathrm{kDa}$ \\
\hline
\end{tabular}

\section{References}

1. Neumann, M.; Sampathu, D.M.; Kwong, L.K.; Truax, A.C.; Micsenyi, M.C.; Chou, T.T.; Bruce, J.; Schuck, T.; Grossman, M.; Clark, C.M.; et al. Ubiquitinated TDP-43 in frontotemporal lobar degeneration and amyotrophic lateral sclerosis. Science 2006, 314, 130-133. [CrossRef] [PubMed]

2. Arai, T.; Hasegawa, M.; Akiyama, H.; Ikeda, K.; Nonaka, T.; Mori, H.; Mann, D.; Tsuchiya, K.; Yoshida, M.; Hashizume, Y.; et al. TDP-43 is a component of ubiquitin-positive tau-negative inclusions in frontotemporal lobar degeneration and amyotrophic lateral sclerosis. Biochem. Biophys. Res. Commun. 2006, 351, 602-611. [CrossRef]

3. Buratti, E.; Dörk, T.; Zuccato, E.; Pagani, F.; Romano, M.; Baralle, F.E. Nuclear factor TDP-43 and SR proteins promote in vitro and in vivo CFTR exon 9 skipping. EMBO J. 2001, 20, 1774-1784. [CrossRef]

4. Brooks, B.; Miller, R.; Swash, M.; Munsat, T. El Escorial revisited: Revised criteria for the diagnosis of amyotrophic lateral sclerosis. Amyotroph. Lateral. Scler. Other Mot. Neuron Disord. 2000, 1, 293-299. [CrossRef]

5. Talbott, E.O.; Malek, A.M.; Lacomis, D. The epidemiology of amyotrophic lateral sclerosis. Handb. Clin. Neurol. 2016, 138, 225-238. [PubMed] 
6. Logroscino, G.; Piccininni, M. Amyotrophic lateral sclerosis descriptive epidemiology: The origin of geographic difference. Neuroepidemiology 2019, 52, 93-103. [CrossRef] [PubMed]

7. Neary, D.; Snowden, J.S.; Gustafson, L.; Passant, U.; Stuss, D.; Black, S.; Freedman, M.; Kertesz, A.; Robert, P.H.; Albert, M.; et al. Frontotemporal lobar degeneration: A consensus on clinical diagnostic criteria. Neurology 1998, 51, 1546-1554. [CrossRef]

8. Coyle-Gilchrist, I.T.; Dick, K.M.; Patterson, K.; Vázquez Rodríquez, P.; Wehmann, E.; Wilcox, A.; Lansdall, C.J.; Dawson, K.E.; Wiggins, J.; Mead, S.; et al. Prevalence, characteristics, and survival of frontotemporal lobar degeneration syndromes. Neurology 2016, 86, 1736-1743. [CrossRef] [PubMed]

9. Rascovsky, K.; Hodges, J.R.; Knopman, D.; Mendez, M.F.; Kramer, J.H.; Neuhaus, J.; van Swieten, J.C.; Seelaar, H.; Dopper, E.G.; Onyike, C.U.; et al. Sensitivity of revised diagnostic criteria for the behavioural variant of frontotemporal dementia. Brain 2011, 134, 2456-2477. [CrossRef]

10. Gorno-Tempini, M.L.; Hillis, A.E.; Weintraub, S.; Kertesz, A.; Mendez, M.; Cappa, S.F.; Ogar, J.M.; Rohrer, J.D.; Black, S.; Boeve, B.F.; et al. Classification of primary progressive aphasia and its variants. Neurology 2011, 76, 1006-1014. [CrossRef]

11. De Boer, E.M.J.; Orie, V.K.; Williams, T.; Baker, M.R.; De Oliveira, H.M.; Polvikoski, T.; Silsby, M.; Menon, P.; van den Bos, M.; Halliday, G.M.; et al. TDP-43 proteinopathies: A new wave of neurodegenerative diseases. J. Neurol. Neurosurg. Psychiatry 2020, 92, 86-95. [CrossRef]

12. Tan, R.H.; Ke, Y.D.; Ittner, L.M.; Halliday, G.M. ALS/FTLD: Experimental models and reality. Acta Neuropathol. 2017, 133, 177-196. [CrossRef]

13. Kwiatkowski, T.J., Jr.; Bosco, D.A.; Leclerc, A.L.; Tamrazian, E.; Vanderburg, C.R.; Russ, C.; Davis, A.; Gilchrist, J.; Kasarskis, E.J.; Munsat, T.; et al. Mutations in the FUS/TLS gene on chromosome 16 cause familial amyotrophic lateral sclerosis. Science 2009, 323, 1205-1208. [CrossRef]

14. Vance, C.; Rogelj, B.; Hortobágyi, T.; De Vos, K.J.; Nishimura, A.L.; Sreedharan, J.; Hu, X.; Smith, B.; Ruddy, D.; Wright, P.; et al. Mutations in FUS, an RNA processing protein, cause familial amyotrophic lateral sclerosis type 6. Science 2009, 323, $1208-1211$. [CrossRef] [PubMed]

15. Hasegawa, M.; Arai, T.; Nonaka, T.; Kametani, F.; Yoshida, M.; Hashizume, Y.; Beach, T.G.; Buratti, E.; Baralle, F.; Morita, M.; et al. Phosphorylated TDP-43 in frontotemporal lobar degeneration and amyotrophic lateral sclerosis. Ann. Neurol. 2008, 64, 60-70. [CrossRef] [PubMed]

16. Nonaka, T.; Masuda-Suzukake, M.; Arai, T.; Hasegawa, Y.; Akatsu, H.; Obi, T.; Yoshida, M.; Murayama, S.; Mann, D.M.; Akiyama, H.; et al. Prion-like properties of pathological TDP-43 aggregates from diseased brains. Cell Rep. 2013, 4, 124-134. [CrossRef] [PubMed]

17. Brettschneider, J.; Arai, K.; Del Tredici, K.; Toledo, J.B.; Robinson, J.L.; Lee, E.B.; Kuwabara, S.; Shibuya, K.; Irwin, D.J.; Fang, L. TDP-43 pathology and neuronal loss in amyotrophic lateral sclerosis spinal cord. Acta Neuropathol. 2014, 128, 423-437. [CrossRef]

18. Mizuno, Y.; Fujita, Y.; Takatama, M.; Okamoto, K. Comparison of phosphorylated TDP-43-positive inclusions in oculomotor neurons in patients with non-ALS and ALS disorders. J. Neurol. Sci. 2012, 315, 20-25. [CrossRef] [PubMed]

19. Mori, F.; Kakita, A.; Takahashi, H.; Wakabayashi, K. Co-localization of Bunina bodies and TDP-43 inclusions in lower motor neurons in amyotrophic lateral sclerosis. Neuropathology 2014, 34, 71-76. [CrossRef]

20. Okamoto, K.; Mizuno, Y.; Fujita, Y. Bunina bodies in amyotrophic lateral sclerosis. Neuropathology 2008, 28, 109-115. [CrossRef]

21. Josephs, K.A.; Hodges, J.R.; Snowden, J.S.; Mackenzie, I.R.; Neumann, M.; Mann, D.M.; Dickson, D.W. Neuropathological background of phenotypical variability in frontotemporal dementia. Acta Neuropathol. 2011, 122, 137-153. [CrossRef] [PubMed]

22. Mackenzie, I.R.; Neumann, M.; Baborie, A.; Sampathu, D.M.; Du Plessis, D.; Jaros, E.; Perry, R.H.; Trojanowski, J.Q.; Mann, D.M.; Lee, V.M. A harmonized classification system for FTLD-TDP pathology. Acta Neuropathol. 2011, 122, 111-113. [CrossRef] [PubMed]

23. Sampathu, D.M.; Neumann, M.; Kwong, L.K.; Chou, T.T.; Micsenyi, M.; Truax, A.; Bruce, J.; Grossman, M.; Trojanowski, J.Q.; Lee, V.M. Pathological heterogeneity of frontotemporal lobar degeneration with ubiquitin-positive inclusions delineated by ubiquitin immunohistochemistry and novel monoclonal antibodies. Am. J. Pathol. 2006, 169, 1343-1352. [CrossRef]

24. Cairns, N.J.; Neumann, M.; Bigio, E.H.; Holm, I.E.; Troost, D.; Hatanpaa, K.J.; Foong, C.; White, C.L., 3rd; Schneider, J.A.; Kretzschmar, H.A.; et al. TDP-43 in familial and sporadic frontotemporal lobar degeneration with ubiquitin inclusions. Am. J. Pathol. 2007, 171, 227-240. [CrossRef]

25. Josephs, K.A.; Stroh, A.; Dugger, B.; Dickson, D.W. Evaluation of subcortical pathology and clinical correlations in FTLD-U subtypes. Acta Neuropathol. 2009, 118, 349-358. [CrossRef]

26. Takeda, T.; Seilhean, D.; Le Ber, I.; Millecamps, S.; Sazdovitch, V.; Kitagawa, K.; Uchihara, T.; Duyckaerts, C. Amygdala TDP-43 pathology in frontotemporal lobar degeneration and motor neuron disease. J. Neuropathol. Exp. Neurol. 2017, 76, 800-812. [CrossRef]

27. Snowden, J.; Neary, D.; Mann, D. Frontotemporal lobar degeneration: Clinical and pathological relationships. Acta Neuropathol. 2007, 114, 31-38. [CrossRef]

28. Geser, F.; Martinez-Lage, M.; Robinson, J.; Uryu, K.; Neumann, M.; Brandmeir, N.J.; Xie, S.X.; Kwong, L.K.; Elman, L.; McCluskey, L.; et al. Clinical and pathological continuum of multisystem TDP-43 proteinopathies. Arch. Neurol. 2009, 66, 180-189. [CrossRef]

29. Riku, Y.; Watanabe, H.; Yoshida, M.; Tatsumi, S.; Mimuro, M.; Iwasaki, Y.; Katsuno, M.; Iguchi, Y.; Masuda, M.; Senda, J.; et al. Lower motor neuron involvement in TAR DNA-binding protein of $43 \mathrm{kDa}$-related frontotemporal lobar degeneration and amyotrophic lateral sclerosis. JAMA Neurol. 2014, 71, 172-179. [CrossRef] 
30. Riku, Y.; Atsuta, N.; Yoshida, M.; Tatsumi, S.; Iwasaki, Y.; Mimuro, M.; Watanabe, H.; Ito, M.; Senda, J.; Nakamura, R.; et al. Differential motor neuron involvement in progressive muscular atrophy: A comparative study with amyotrophic lateral sclerosis. BMJ Open 2014, 4, e005213. [CrossRef] [PubMed]

31. Tsuji, H.; Arai, T.; Kametani, F.; Nonaka, T.; Yamashita, M.; Suzukake, M.; Hosokawa, M.; Yoshida, M.; Hatsuta, H.; Takao, M.; et al. Molecular analysis and biochemical classification of TDP-43 proteinopathy. Brain 2012, 135, 3380-3391. [CrossRef]

32. Laferrière, F.; Maniecka, Z.; Pérez-Berlanga, M.; Hruska-Plochan, M.; Gilhespy, L.; Hock, E.M.; Wagner, U.; Afroz, T.; Boersema, P.J.; Barmettler, G.; et al. TDP-43 extracted from frontotemporal lobar degeneration subject brains displays distinct aggregate assemblies and neurotoxic effects reflecting disease progression rates. Nat. Neurosci. 2019, 22, 65-77. [CrossRef] [PubMed]

33. Wils, H.; Kleinberger, G.; Janssens, J.; Pereson, S.; Joris, G.; Cuijt, I.; Smits, V.; Ceuterick-de Groote, C.; Van Broeckhoven, C.; KumarSingh, S. TDP-43 transgenic mice develop spastic paralysis and neuronal inclusions characteristic of ALS and frontotemporal lobar degeneration. Proc. Natl. Acad. Sci. USA 2010, 107, 3858-3863. [CrossRef]

34. Baskaran, P.; Shaw, C.; Guthrie, S. TDP-43 causes neurotoxicity and cytoskeletal dysfunction in primary cortical neurons. PLoS ONE 2018, 13, e0196528. [CrossRef] [PubMed]

35. Ebstein, S.Y.; Yagudayeva, I.; Shneider, N.A. Mutant TDP-43 causes early-stage dose-dependent motor neuron degeneration in a TARDBP knock in mouse model of ALS. Cell Rep. 2019, 26, 364-373.e4. [CrossRef] [PubMed]

36. Winton, M.J.; Igaz, L.M.; Wong, M.M.; Kwong, L.K.; Trojanowski, J.Q.; Lee, V.M. Disturbance of nuclear and cytoplasmic TAR DNA-binding protein (TDP-43) induces disease-like redistribution, sequestration, and aggregate formation. J. Biol. Chem. 2008, 283, 13302-13309. [CrossRef] [PubMed]

37. Igaz, L.M.; Kwong, L.K.; Lee, E.B.; Chen-Plotkin, A.; Swanson, E.; Unger, T.; Malunda, J.; Xu, Y.; Winton, M.J.; Trojanowski, J.Q.; et al. Dysregulation of the ALS-associated gene TDP-43 leads to neuronal death and degeneration in mice. J. Clin. Invest. 2011, 121, 726-738. [CrossRef] [PubMed]

38. Wu, L.S.; Cheng, W.C.; Chen, C.Y.; Wu, M.C.; Wang, Y.C.; Tseng, Y.H.; Chuang, T.J.; Shen, C.J. Transcriptomopathies of pre- and post-symptomatic frontotemporal dementia-like mice with TDP-43 depletion in forebrain neurons. Acta Neuropathol. Commun. 2019, 7, 50. [CrossRef] [PubMed]

39. Mitra, J.; Guerrero, E.N.; Hegde, P.M.; Liachko, N.F.; Wang, H.; Vasquez, V.; Gao, J.; Pandey, A.; Taylor, J.P.; Kraemer, B.C.; et al. Motor neuron disease-associated loss of nuclear TDP-43 is linked to DNA double-strand break repair defects. Proc. Natl. Acad. Sci. USA 2019, 116, 4696-4705. [CrossRef] [PubMed]

40. Donde, A.; Sun, M.; Ling, J.P.; Braunstein, K.E.; Pang, B.; Wen, X.; Cheng, X.; Chen, L.; Wong, P.C. Splicing repression is a major function of TDP-43 in motor neurons. Acta Neuropathol. 2019, 138, 813-826. [CrossRef]

41. Saldi, T.K.; Ash, P.E.; Wilson, G.; Gonzales, P.; Garrido-Lecca, A.; Roberts, C.M.; Dostal, V.; Gendron, T.F.; Stein, L.D.; Blumenthal, T.; et al. TDP-1, the Caenorhabditis elegans ortholog of TDP-43, limits the accumulation of double-stranded RNA. EMBO J. 2014, 33, 2947-2966. [CrossRef]

42. Braak, H.; Brettschneider, J.; Ludolph, A.C.; Lee, V.M.; Trojanowski, J.Q.; Del Tredici, K. Amyotrophic lateral sclerosis-A model of corticofugal axonal spread. Nat. Rev. Neurol. 2013, 9, 708-714. [CrossRef]

43. Brettschneider, J.; Del Tredici, K.; Toledo, J.B.; Robinson, J.L.; Irwin, D.J.; Grossman, M.; Suh, E.; Van Deerlin, V.M.; Wood, E.M.; Baek, Y.; et al. Stages of pTDP-43 pathology in amyotrophic lateral sclerosis. Ann. Neurol. 2013, 74, 20-38. [CrossRef]

44. Brettschneider, J.; Del Tredici, K.; Irwin, D.J.; Grossman, M.; Robinson, J.L.; Toledo, J.B.; Fang, L.; Van Deerlin, V.M.; Ludolph, A.C.; Lee, V.M.; et al. Sequential distribution of pTDP-43 pathology in behavioral variant frontotemporal dementia (bvFTD). Acta Neuropathol. 2014, 127, 423-439. [CrossRef] [PubMed]

45. Riku, Y.; Watanabe, H.; Yoshida, M.; Mimuro, M.; Iwasaki, Y.; Masuda, M.; Ishigaki, S.; Katsuno, M.; Sobue, G. Marked involvement of the striatal efferent system in TAR DNA-binding protein $43 \mathrm{kDa}$-related frontotemporal lobar degeneration and amyotrophic lateral sclerosis. J. Neuropathol. Exp. Neurol. 2016, 75, 801-811. [CrossRef] [PubMed]

46. Riku, Y.; Watanabe, H.; Yoshida, M.; Mimuro, M.; Iwasaki, Y.; Masuda, M.; Ishigaki, S.; Katsuno, M.; Sobue, G. Pathologic involvement of glutamatergic striatal inputs from the cortices in TAR DNA-binding protein 43 kDa-related frontotemporal lobar degeneration and amyotrophic lateral sclerosis. J. Neuropathol. Exp. Neurol. 2017, 76, 759-768. [CrossRef] [PubMed]

47. Riku, Y. Reappraisal of the anatomical spreading and propagation hypothesis about TDP-43 aggregation in amyotrophic lateral sclerosis and frontotemporal lobar degeneration. Neuropathology 2020, 40, 426-435. [CrossRef]

48. Van den Bos, M.A.J.; Geevasinga, N.; Higashihara, M.; Menon, P.; Vucic, S. Pathophysiology and diagnosis of ALS: Insights from advances in neurophysiological techniques. Int. J. Mol. Sci. 2019, 20, 2818. [CrossRef]

49. Müller, H.P.; Turner, M.R.; Grosskreutz, J.; Abrahams, S.; Bede, P.; Govind, V.; Prudlo, J.; Ludolph, A.C.; Filippi, M.; Kassubek, J.; et al. A large-scale multicentre cerebral diffusion tensor imaging study in amyotrophic lateral sclerosis. J. Neurol. Neurosurg. Psychiatry 2016, 87, 570-579. [CrossRef]

50. Schmidt, R.; de Reus, M.A.; Scholtens, L.H.; van den Berg, L.H.; van den Heuvel, M.P. Simulating disease propagation across white matter connectome reveals anatomical substrate for neuropathology staging in amyotrophic lateral sclerosis. Neuroimage 2016, 124, 762-769. [CrossRef]

51. Trojsi, F.; Caiazzo, G.; Corbo, D.; Piccirillo, G.; Cristillo, V.; Femiano, C.; Ferrantino, T.; Cirillo, M.; Monsurrò, M.R.; Esposito, F.; et al. Microstructural changes across different clinical milestones of disease in amyotrophic lateral sclerosis. PLoS ONE 2015, 10, e0119045. [CrossRef] 
52. Schulthess, I.; Gorges, M.; Müller, H.P.; Lulé, D.; Del Tredici, K.; Ludolph, A.C.; Kassubek, J. Functional connectivity changes resemble patterns of pTDP-43 pathology in amyotrophic lateral sclerosis. Sci. Rep. 2016, 6, 38391. [CrossRef] [PubMed]

53. Takeda, T.; Iijima, M.; Uchihara, T.; Ohashi, T.; Seilhean, D.; Duyckaerts, C.; Uchiyama, S. TDP-43 pathology progression along the olfactory pathway as a possible substrate for olfactory impairment in amyotrophic lateral sclerosis. J. Neuropathol. Exp. Neurol. 2015, 74, 547-556. [CrossRef] [PubMed]

54. Takeda, T.; Uchihara, T.; Arai, N.; Mizutani, T.; Iwata, M. Progression of hippocampal degeneration in amyotrophic lateral sclerosis with or without memory impairment: Distinction from Alzheimer disease. Acta Neuropathol. 2009, 117, 35-44. [CrossRef]

55. Dedeene, L.; Van Schoor, E.; Vandenberghe, R.; Van Damme, P.; Poesen, K.; Thal, D.R. Circadian sleep/wake-associated cells show dipeptide repeat protein aggregates in C9orf72-related ALS and FTLD cases. Acta Neuropathol. Commun. 2019, 7, 189. [CrossRef]

56. Porta, S.; Xu, Y.; Restrepo, C.R.; Kwong, L.K.; Zhang, B.; Brown, H.J.; Lee, E.B.; Trojanowski, J.Q.; Lee, V.M. Patient-derived frontotemporal lobar degeneration brain extracts induce formation and spreading of TDP-43 pathology in vivo. Nat. Commun. 2018, 9, 4220. [CrossRef] [PubMed]

57. Sasaki, S.; Iwata, M. Ultrastructural change of synapses of Betz cells in patients with amyotrophic lateral sclerosis. Neurosci. Lett. 1999, 268, 29-32. [CrossRef]

58. Sasaki, S.; Iwata, M. Ultrastructural study of synapses in the anterior horn neurons of patients with amyotrophic lateral sclerosis. Neurosci. Lett. 1996, 204, 53-56. [CrossRef]

59. Henstridge, C.M.; Sideris, D.I.; Carroll, E.; Rotariu, S.; Salomonsson, S.; Tzioras, M.; McKenzie, C.A.; Smith, C.; von Arnim, C.A.F.; Ludolph, A.C.; et al. Synapse loss in the prefrontal cortex is associated with cognitive decline in amyotrophic lateral sclerosis. Acta Neuropathol. 2018, 135, 213-226. [CrossRef]

60. Fallini, C.; Bassell, G.J.; Rossoll, W. The ALS disease protein TDP-43 is actively transported in motor neuron axons and regulates axon outgrowth. Hum. Mol. Genet. 2012, 21, 3703-3718. [CrossRef]

61. Heyburn, L.; Hebron, M.L.; Smith, J.; Winston, C.; Bechara, J.; Li, Z.; Lonskaya, I.; Burns, M.P.; Harris, B.T.; Moussa, C.E. Tyrosine kinase inhibition reverses TDP-43 effects on synaptic protein expression, astrocytic function and amino acid dis-homeostasis. J. Neurochem. 2016, 139, 610-623. [CrossRef] [PubMed]

62. Zhou, L.; McInnes, J.; Wierda, K.; Holt, M.; Herrmann, A.G.; Jackson, R.J.; Wang, Y.C.; Swerts, J.; Beyens, J.; Miskiewicz, K.; et al. Tau association with synaptic vesicles causes presynaptic dysfunction. Nat. Commun. 2017, 8, 15295. [CrossRef]

63. Paolicelli, R.C.; Jawaid, A.; Henstridge, C.M.; Valeri, A.; Merlini, M.; Robinson, J.L.; Lee, E.B.; Rose, J.; Appel, S.; Lee, V.M.; et al. TDP-43 depletion in microglia promotes amyloid clearance but also induces synapse loss. Neuron 2017, 95, 297-308.e6. [CrossRef] [PubMed]

64. Schmid, B.; Hruscha, A.; Hogl, S.; Banzhaf-Strathmann, J.; Strecker, K.; van der Zee, J.; Teucke, M.; Eimer, S.; Hegermann, J.; Kittelmann, M.; et al. Loss of ALS-associated TDP-43 in zebrafish causes muscle degeneration, vascular dysfunction, and reduced motor neuron axon outgrowth. Proc. Natl. Acad. Sci. USA 2013, 110, 4986-4991. [CrossRef] [PubMed]

65. Klim, J.R.; Williams, L.A.; Limone, F.; Guerra San Juan, I.; Davis-Dusenbery, B.N.; Mordes, D.A.; Burberry, A.; Steinbaugh, M.J.; Gamage, K.K.; Kirchner, R.; et al. ALS-implicated protein TDP-43 sustains levels of STMN2, a mediator of motor neuron growth and repair. Nat. Neurosci. 2019, 22, 167-179. [CrossRef]

66. Udagawa, T.; Fujioka, Y.; Tanaka, M.; Honda, D.; Yokoi, S.; Riku, Y.; Ibi, D.; Nagai, T.; Yamada, K.; Watanabe, H.; et al. FUS regulates AMPA receptor function and FTLD/ALS-associated behaviour via GluA1 mRNA stabilization. Nat. Commun. 2015, 6 , 7098. [CrossRef]

67. Johansen, T.; Lamark, T. Selective autophagy mediated by autophagic adapter proteins. Autophagy 2011, 7, 279-296. [CrossRef]

68. Sasaki, S. Autophagy in spinal cord motor neurons in sporadic amyotrophic lateral sclerosis. J. Neuropathol. Exp. Neurol. 2011, 70, 349-359. [CrossRef]

69. Barmada, S.J.; Serio, A.; Arjun, A.; Bilican, B.; Daub, A.; Ando, D.M.; Tsvetkov, A.; Pleiss, M.; Li, X.; Peisach, D.; et al. Autophagy induction enhances TDP43 turnover and survival in neuronal ALS models. Nat. Chem. Biol. 2014, 10, 677-685. [CrossRef]

70. Jo, M.; Lee, S.; Kim, K.; Lee, S.; Kim, S.R.; Kim, H.J. Inhibition of MEK5 suppresses TDP-43 toxicity via the mTOR-independent activation of the autophagy-lysosome pathway. Biochem. Biophys. Res. Commun. 2019, 513, 925-932. [CrossRef]

71. Leibiger, C.; Deisel, J.; Aufschnaiter, A.; Ambros, S.; Tereshchenko, M.; Verheijen, B.M.; Büttner, S.; Braun, R.J. TDP-43 controls lysosomal pathways thereby determining its own clearance and cytotoxicity. Hum. Mol. Genet. 2018, 27, 1593-1607. [CrossRef] [PubMed]

72. Iguchi, Y.; Eid, L.; Parent, M.; Soucy, G.; Bareil, C.; Riku, Y.; Kawai, K.; Takagi, S.; Yoshida, M.; Katsuno, M.; et al. Exosome secretion is a key pathway for clearance of pathological TDP-43. Brain 2016, 139, 3187-3201. [CrossRef] [PubMed]

73. Sproviero, D.; La Salvia, S.; Giannini, M.; Crippa, V.; Gagliardi, S.; Bernuzzi, S.; Diamanti, L.; Ceroni, M.; Pansarasa, O.; Poletti, A.; et al. Pathological proteins are transported by extracellular vesicles of sporadic amyotrophic lateral sclerosis patients. Front. Neurosci. 2018, 12, 487. [CrossRef] [PubMed]

74. Chen, P.C.; Wu, D.; Hu, C.J.; Chen, H.Y.; Hsieh, Y.C.; Huang, C.C. Exosomal TAR DNA-binding protein-43 and neurofilaments in plasma of amyotrophic lateral sclerosis patients: A longitudinal follow-up study. J. Neurol. Sci. 2020, 418, 117070. [CrossRef]

75. Hardy, J.; Rogaeva, E. Motor neuron disease and frontotemporal dementia: Sometimes related, sometimes not. Exp. Neurol. 2014, 262, 75-83. [CrossRef] 
76. Smith, K.R.; Damiano, J.; Franceschetti, S.; Carpenter, S.; Canafoglia, L.; Morbin, M.; Rossi, G.; Pareyson, D.; Mole, S.E.; Staropoli, J.F.; et al. Strikingly different clinicopathological phenotypes determined by progranulin-mutation dosage. Am. J. Hum. Genet. 2012, 90, 1102-1107. [CrossRef]

77. Shi, Y.; Lin, S.; Staats, K.A.; Li, Y.; Chang, W.H.; Hung, S.T.; Hendricks, E.; Linares, G.R.; Wang, Y.; Son, E.Y.; et al. Haploinsufficiency leads to neurodegeneration in C9ORF72 ALS/FTD human induced motor neurons. Nat. Med. 2018, $24,313-325$. [CrossRef]

78. Riku, Y.; Duyckaerts, C.; Boluda, S.; Plu, I.; Le Ber, I.; Millecamps, S.; Salachas, F.; Yoshida, M.; Ando, T.; Brainbank NeuroCEB Neuropathology Network. Increased prevalence of granulovacuolar degeneration in C9orf72 mutation. Acta Neuropathol. 2019, 138, 783-793. [CrossRef]

79. Mori, K.; Weng, S.M.; Arzberger, T.; May, S.; Rentzsch, K.; Kremmer, E.; Schmid, B.; Kretzschmar, H.A.; Cruts, M.; Van Broeckhoven, C.; et al. The C9orf72 GGGGCC repeat is translated into aggregating dipeptide-repeat proteins in FTLD/ALS. Science 2013, 339, 1335-1338. [CrossRef]

80. Skibinski, G.; Parkinson, N.J.; Brown, J.M.; Chakrabarti, L.; Lloyd, S.L.; Hummerich, H.; Nielsen, J.E.; Hodges, J.R.; Spillantini, M.G.; Thusgaard, T.; et al. Mutations in the endosomal ESCRTIII-complex subunit CHMP2B in frontotemporal dementia. Nat. Genet. 2005, 37, 806-808. [CrossRef]

81. Van Schoor, E.; Koper, M.J.; Ospitalieri, S.; Dedeene, L.; Tomé, S.O.; Vandenberghe, R.; Brenner, D.; Otto, M.; Weishaupt, J.; Ludolph, A.C.; et al. Necrosome-positive granulovacuolar degeneration is associated with TDP-43 pathological lesions in the hippocampus of ALS/FTLD cases. Neuropathol. Appl. Neurobiol. 2021, 47, 328-345. [CrossRef]

82. Adachi, H.; Katsuno, M.; Minamiyama, M.; Sang, C.; Pagoulatos, G.; Angelidis, C.; Kusakabe, M.; Yoshiki, A.; Kobayashi, Y.; Doyu, M.; et al. Heat shock protein 70 chaperone overexpression ameliorates phenotypes of the spinal and bulbar muscular atrophy transgenic mouse model by reducing nuclear-localized mutant androgen receptor protein. J. Neurosci. 2003, 23, $2203-2211$. [CrossRef] [PubMed]

83. Kondo, N.; Katsuno, M.; Riku, Y.; Sobue, G. HSF inhibits the progression of age-related neurodegenerative diseases. In Heat Shock Factor; Springer: Tokyo, Japan, 2016; pp. 213-242.

84. Chen, H.J.; Mitchell, J.C.; Novoselov, S.; Miller, J.; Nishimura, A.L.; Scotter, E.L.; Vance, C.A.; Cheetham, M.E.; Shaw, C.E. The heat shock response plays an important role in TDP-43 clearance: Evidence for dysfunction in amyotrophic lateral sclerosis. Brain 2016, 139, 1417-1432. [CrossRef]

85. Ormeño, F.; Hormazabal, J.; Moreno, J.; Riquelme, F.; Rios, J.; Criollo, A.; Albornoz, A.; Alfaro, I.E.; Budini, M. Chaperone mediated autophagy degrades TDP-43 protein and is affected by TDP-43 aggregation. Front. Mol. Neurosci. 2020, 13, 19. [CrossRef]

86. Yu, H.; Lu, S.; Gasior, K.; Singh, D.; Vazquez-Sanchez, S.; Tapia, O.; Toprani, D.; Beccari, M.S.; Yates, J.R., 3rd; Da Cruz, S.; et al. HSP70 chaperones RNA-free TDP-43 into anisotropic intranuclear liquid spherical shells. Science 2021, 371, eabb4309. [CrossRef]

87. Braak, H.; Ludolph, A.C.; Neumann, M.; Ravits, J.; Del Tredici, K. Pathological TDP-43 changes in Betz cells differ from those in bulbar and spinal $\alpha$-motoneurons in sporadic amyotrophic lateral sclerosis. Acta Neuropathol. 2017, 133, 79-90. [CrossRef]

88. Giordana, M.T.; Piccinini, M.; Grifoni, S.; De Marco, G.; Vercellino, M.; Magistrello, M.; Pellerino, A.; Buccinnà, B.; Lupino, E.; Rinaudo, M.T. TDP-43 redistribution is an early event in sporadic amyotrophic lateral sclerosis. Brain Pathol. 2010, $20,351-360$. [CrossRef] [PubMed]

89. Pasetto, L.; Pozzi, S.; Castelnovo, M.; Basso, M.; Estevez, A.G.; Fumagalli, S.; De Simoni, M.G.; Castellaneta, V.; Bigini, P.; Restelli, E.; et al. Targeting extracellular cyclophilin A reduces neuroinflammation and extends survival in a mouse model of amyotrophic lateral sclerosis. J. Neurosci. 2017, 37, 1413-1427. [CrossRef] [PubMed]

90. Smethurst, P.; Risse, E.; Tyzack, G.E.; Mitchell, J.S.; Taha, D.M.; Chen, Y.R.; Newcombe, J.; Collinge, J.; Sidle, K.; Patani, R. Distinct responses of neurons and astrocytes to TDP-43 proteinopathy in amyotrophic lateral sclerosis. Brain 2020, 143, 430-440. [CrossRef]

91. Spiller, K.J.; Restrepo, C.R.; Khan, T.; Dominique, M.A.; Fang, T.C.; Canter, R.G.; Roberts, C.J.; Miller, K.R.; Ransohoff, R.M.; Trojanowski, J.Q.; et al. Microglia-mediated recovery from ALS-relevant motor neuron degeneration in a mouse model of TDP-43 proteinopathy. Nat. Neurosci. 2018, 21, 329-340. [CrossRef]

92. LaRocca, T.J.; Mariani, A.; Watkins, L.R.; Link, C.D. TDP-43 knockdown causes innate immune activation via protein kinase R in astrocytes. Neurobiol. Dis. 2019, 132, 104514. [CrossRef]

93. Haidet-Phillips, A.M.; Gross, S.K.; Williams, T.; Tuteja, A.; Sherman, A.; Ko, M.; Jeong, Y.H.; Wong, P.C.; Maragakis, N.J. Altered astrocytic expression of TDP-43 does not influence motor neuron survival. Exp. Neurol. 2013, 250, 250-259. [CrossRef]

94. Josephs, K.A.; Martin, P.R.; Weigand, S.D.; Tosakulwong, N.; Buciuc, M.; Murray, M.E.; Petrucelli, L.; Senjem, M.L.; Spychalla, A.J.; Knopman, D.S.; et al. Protein contributions to brain atrophy acceleration in Alzheimer's disease and primary age-related tauopathy. Brain 2020, 143, 3463-3476. [CrossRef]

95. Tomé, S.O.; Vandenberghe, R.; Ospitalieri, S.; Van Schoor, E.; Tousseyn, T.; Otto, M.; von Arnim, C.A.F.; Thal, D.R. Distinct molecular patterns of TDP-43 pathology in Alzheimer's disease: Relationship with clinical phenotypes. Acta Neuropathol. Commun. 2020, 8, 61. [CrossRef] [PubMed]

96. Koga, S.; Sanchez-Contreras, M.; Josephs, K.A.; Uitti, R.J.; Graff-Radford, N.; van Gerpen, J.A.; Cheshire, W.P.; Wszolek, Z.K.; Rademakers, R.; Dickson, D.W. Distribution and characteristics of transactive response DNA binding protein $43 \mathrm{kDa}$ pathology in progressive supranuclear palsy. Mov. Disord. 2017, 32, 246-255. [CrossRef] [PubMed] 
97. Koga, S.; Kouri, N.; Walton, R.L.; Ebbert, M.T.W.; Josephs, K.A.; Litvan, I.; Graff-Radford, N.; Ahlskog, J.E.; Uitti, R.J.; van Gerpen, J.A.; et al. Corticobasal degeneration with TDP-43 pathology presenting with progressive supranuclear palsy syndrome: A distinct clinicopathologic subtype. Acta Neuropathol. 2018, 136, 389-404. [CrossRef]

98. McAleese, K.E.; Walker, L.; Erskine, D.; Thomas, A.J.; McKeith, I.G.; Attems, J. TDP-43 pathology in Alzheimer's disease, dementia with Lewy bodies and ageing. Brain Pathol. 2017, 27, 472-479. [CrossRef]

99. Aoki, N.; Murray, M.E.; Ogaki, K.; Fujioka, S.; Rutherford, N.J.; Rademakers, R.; Ross, O.A.; Dickson, D.W. Hippocampal sclerosis in Lewy body disease is a TDP-43 proteinopathy similar to FTLD-TDP Type A. Acta Neuropathol. 2015, 129, 53-64. [CrossRef] [PubMed]

100. Nakashima-Yasuda, H.; Uryu, K.; Robinson, J.; Xie, S.X.; Hurtig, H.; Duda, J.E.; Arnold, S.E.; Siderowf, A.; Grossman, M.; Leverenz, J.B.; et al. Co-morbidity of TDP-43 proteinopathy in Lewy body related diseases. Acta Neuropathol. 2007, 114, 221-229. [CrossRef] [PubMed]

101. Higashi, S.; Iseki, E.; Yamamoto, R.; Minegishi, M.; Hino, H.; Fujisawa, K.; Togo, T.; Katsuse, O.; Uchikado, H.; Furukawa, Y.; et al. Concurrence of TDP-43, tau and alpha-synuclein pathology in brains of Alzheimer's disease and dementia with Lewy bodies. Brain Res. 2007, 1184, 284-294. [CrossRef]

102. Amador-Ortiz, C.; Lin, W.L.; Ahmed, Z.; Personett, D.; Davies, P.; Duara, R.; Graff-Radford, N.R.; Hutton, M.L.; Dickson, D.W. TDP-43 immunoreactivity in hippocampal sclerosis and Alzheimer's disease. Ann. Neurol. 2007, 61, 435-445. [CrossRef]

103. Ling, H.; Kara, E.; Bandopadhyay, R.; Hardy, J.; Holton, J.; Xiromerisiou, G.; Lees, A.; Houlden, H.; Revesz, T. TDP-43 pathology in a patient carrying G2019S LRRK2 mutation and a novel p.Q124E MAPT. Neurobiol Aging. 2013, 34, 2889.e5-2889.e9. [CrossRef]

104. Kenney, K.; Iacono, D.; Edlow, B.L.; Katz, D.I.; Diaz-Arrastia, R.; Dams-O'Connor, K.; Daneshvar, D.H.; Stevens, A.; Moreau, A.L.; Tirrell, L.S.; et al. Dementia after moderate-severe traumatic brain injury: Coexistence of multiple proteinopathies. J. Neuropathol. Exp. Neurol. 2018, 77, 50-63. [CrossRef] [PubMed]

105. Nelson, P.T.; Dickson, D.W.; Trojanowski, J.Q.; Jack, C.R.; Boyle, P.A.; Arfanakis, K.; Rademakers, R.; Alafuzoff, I.; Attems, J.; Brayne, C.; et al. Limbic-predominant age-related TDP-43 encephalopathy (LATE): Consensus working group report. Brain 2019, 142, 1503-1527. [CrossRef]

106. Robinson, J.L.; Yan, N.; Caswell, C.; Xie, S.X.; Suh, E.; Van Deerlin, V.M.; Gibbons, G.; Irwin, D.J.; Grossman, M.; Lee, E.B.; et al. Primary tau pathology, not copathology, correlates with clinical symptoms in PSP and CBD. J. Neuropathol. Exp. Neurol. 2020, 79, 296-304. [CrossRef]

107. Duyckaerts, C.; Braak, H.; Brion, J.P.; Buée, L.; Del Tredici, K.; Goedert, M.; Halliday, G.; Neumann, M.; Spillantini, M.G.; Tolnay, M.; et al. PART is part of Alzheimer disease. Acta Neuropathol. 2015, 129, 749-756. [CrossRef] [PubMed]

108. Stevens, C.H.; Guthrie, N.J.; van Roijen, M.; Halliday, G.M.; Ooi, L. Increased tau phosphorylation in motor neurons from clinically pure sporadic amyotrophic lateral sclerosis patients. J. Neuropathol. Exp. Neurol. 2019, 78, 605-614. [CrossRef] [PubMed]

109. Behrouzi, R.; Liu, X.; Wu, D.; Robinson, A.C.; Tanaguchi-Watanabe, S.; Rollinson, S.; Shi, J.; Tian, J.; Hamdalla, H.H.; Ealing, J.; et al. Pathological tau deposition in motor neurone disease and frontotemporal lobar degeneration associated with TDP-43 proteinopathy. Acta Neuropathol. Commun. 2016, 4, 33. [CrossRef] [PubMed]

110. Bieniek, K.F.; Murray, M.E.; Rutherford, N.J.; Castanedes-Casey, M.; DeJesus-Hernandez, M.; Liesinger, A.M.; Baker, M.C.; Boylan, K.B.; Rademakers, R.; Dickson, D.W. Tau pathology in frontotemporal lobar degeneration with C9ORF72 hexanucleotide repeat expansion. Acta Neuropathol. 2013, 125, 289-302. [CrossRef]

111. Robinson, A.C.; Thompson, J.C.; Weedon, L.; Rollinson, S.; Pickering-Brown, S.; Snowden, J.S.; Davidson, Y.S.; Mann, D.M. No interaction between tau and TDP-43 pathologies in either frontotemporal lobar degeneration or motor neurone disease. Neuropathol. Appl. Neurobiol. 2014, 40, 844-854. [CrossRef] [PubMed]

112. Mimuro, M.; Yoshida, M.; Kuzuhara, S.; Kokubo, Y. Amyotrophic lateral sclerosis and parkinsonism-dementia complex of the Hohara focus of the Kii Peninsula: A multiple proteinopathy? Neuropathology 2018, 38, 98-107. [CrossRef] [PubMed]

113. Verheijen, B.M.; Morimoto, S.; Sasaki, R.; Oyanagi, K.; Kokubo, Y.; Kuzuhara, S.; van Leeuwen, F.W. Expression of mutant ubiquitin and proteostasis impairment in Kii amyotrophic lateral sclerosis/parkinsonism-dementia complex brains. J. Neuropathol. Exp. Neurol. 2020, 79, 902-907. [CrossRef] [PubMed]

114. Ishigaki, S.; Riku, Y.; Fujioka, Y.; Endo, K.; Iwade, N.; Kawai, K.; Ishibashi, M.; Yokoi, S.; Katsuno, M.; Watanabe, H.; et al. Aberrant interaction between FUS and SFPQ in neurons in a wide range of FTLD spectrum diseases. Brain 2020, 143, 2398-2405. [CrossRef]

115. Ishigaki, S.; Fujioka, Y.; Okada, Y.; Riku, Y.; Udagawa, T.; Honda, D.; Yokoi, S.; Endo, K.; Ikenaka, K.; Takagi, S.; et al. Altered tau isoform ratio caused by loss of FUS and SFPQ function leads to FTLD-like phenotypes. Cell Rep. 2017, 18, 1118-1131. [CrossRef] [PubMed]

116. White, M.A.; Kim, E.; Duffy, A.; Adalbert, R.; Phillips, B.U.; Peters, O.M.; Stephenson, J.; Yang, S.; Massenzio, F.; Lin, Z.; et al. TDP-43 gains function due to perturbed autoregulation in a Tardbp knock-in mouse model of ALS-FTD. Nat. Neurosci. 2018, 21, 552-563. [CrossRef]

117. Yokoyama, J.S.; Karch, C.M.; Fan, C.C.; Bonham, L.W.; Kouri, N.; Ross, O.A.; Rademakers, R.; Kim, J.; Wang, Y.; Höglinger, G.U.; et al. Shared genetic risk between corticobasal degeneration, progressive supranuclear palsy, and frontotemporal dementia. Acta Neuropathol. 2017, 133, 825-837. [CrossRef] 
118. Karch, C.M.; Wen, N.; Fan, C.C.; Yokoyama, J.S.; Kouri, N.; Ross, O.A.; Höglinger, G.; Müller, U.; Ferrari, R.; Hardy, J.; et al. Selective genetic overlap between amyotrophic lateral sclerosis and diseases of the frontotemporal dementia spectrum. JAMA Neurol. 2018, 75, 860-875. [CrossRef] [PubMed]

119. Cali, C.P.; Patino, M.; Tai, Y.K.; Ho, W.Y.; McLean, C.A.; Morris, C.M.; Seeley, W.W.; Miller, B.L.; Gaig, C.; Vonsattel, J.P.G.; et al C9orf72 intermediate repeats are associated with corticobasal degeneration, increased C9orf72 expression and disruption of autophagy. Acta Neuropathol. 2019, 138, 795-811. [CrossRef]

120. Uryu, K.; Nakashima-Yasuda, H.; Forman, M.S.; Kwong, L.K.; Clark, C.M.; Grossman, M.; Miller, B.L.; Kretzschmar, H.A.; Lee, V.M.; Trojanowski, J.Q.; et al. Concomitant TAR-DNA-binding protein 43 pathology is present in Alzheimer disease and corticobasal degeneration but not in other tauopathies. J. Neuropathol. Exp. Neurol. 2008, 67, 555-564. [CrossRef] 